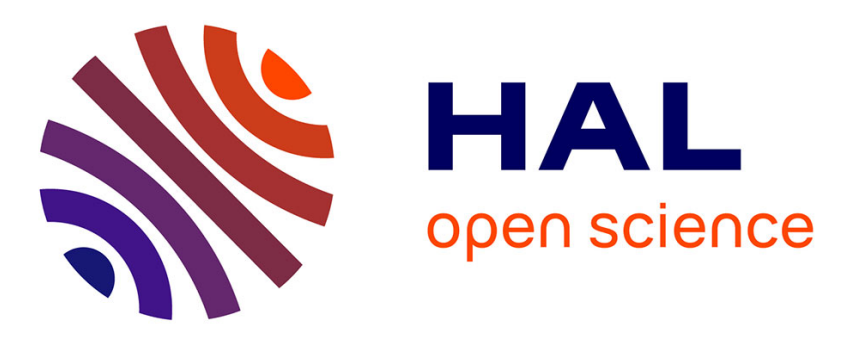

\title{
New age data for Mid-Atlantic Ridge hydrothermal sites' TAG and Snakepit chronology revisited
}

Claude Lalou, Jean-Louis Reyss, Evelyne Brichet, Maurice Arnold, Geoffrey

Thompson, Yves Fouquet, Peter Rona

\section{- To cite this version:}

Claude Lalou, Jean-Louis Reyss, Evelyne Brichet, Maurice Arnold, Geoffrey Thompson, et al.. New age data for Mid-Atlantic Ridge hydrothermal sites' TAG and Snakepit chronology revisited. Journal of Geophysical Research, 1993, 98 (B6), pp.9705. 10.1029/92JB01898 . hal-03584959

\section{HAL Id: hal-03584959 \\ https://hal.science/hal-03584959}

Submitted on 22 Feb 2022

HAL is a multi-disciplinary open access archive for the deposit and dissemination of scientific research documents, whether they are published or not. The documents may come from teaching and research institutions in France or abroad, or from public or private research centers.
L'archive ouverte pluridisciplinaire HAL, est destinée au dépôt et à la diffusion de documents scientifiques de niveau recherche, publiés ou non, émanant des établissements d'enseignement et de recherche français ou étrangers, des laboratoires publics ou privés. 


\title{
New Age Data for Mid-Atlantic Ridge Hydrothermal Sites: TAG and Snakepit Chronology Revisited
}

\author{
Claude Lalou, ${ }^{1}$ Jean-Louis Reyss, ${ }^{1}$ Evelyne Brichet, ${ }^{1}$ Maurice ARnold, ${ }^{1}$ \\ GEOFFREY THOMPSON, ${ }^{2}$ YVES FOUQUET, ${ }^{3}$ AND PETER A. RONA 4
}

\begin{abstract}
The chronologies of TAG and Snakepit hydrothermal fields have been established using ${ }^{210} \mathrm{~Pb} / \mathrm{Pb}$, ${ }^{230} \mathrm{Th} /{ }^{234} \mathrm{U}$ and ${ }^{14} \mathrm{C}$ dating. At the TAG field, a Mn-oxide record, indicative of low temperature events, began at least 125,000 years and possibly 140,000 years ago with maximum intensities at 15,000,7000 and 4000 years before present. High temperature events, giving rise to sulfide deposits, began about 100,000 years ago and have been intermittent to the present day. A presently active site has experienced intermittent pulses of activity every 4000 to 6000 years over the past 20,000 years. Decrease in activity is often marked by low temperature aragonite precipitation in chimney conduits at 4000,7000 and 9000 years ago. After a period of quiescence lasting about 4000 years this site was reactivated about 50 years ago. The Snakepit field is much younger and no sulfides older than $\mathbf{4 0 0 0}$ years have been recovered. Relict sulfide deposits are dated between 2000 and 4000 years old indicating this site was active during a quiescent period at TAG. Reactivation of Snakepit. took place about 80 years ago, and is presently concurrent with that of TAG. Comparison with hydrothermal sites on the East Pacific Rise suggests that on slow spreading ridges the major fracture systems focussing the hydrothermal discharge can be reactivated at intervals and new deposits precipitated on top of older ones, while on faster spreading ridges each pulse of activity is separated in space and time resulting in discrete deposits.
\end{abstract}

\section{INTRODUCTION}

On fast spreading ridges like the East Pacific Rise (EPR), only active or very recent hydrothermal fields are found in or close to the rift valley. To obtain fossil sulfides, it is necessary to leave the axial valley and to explore the ridge slopes; finding sulfides here is not easy because of the relatively limited range of submersibles and because no precise target can be defined by remote geophysical or geochemical methods. Moreover, on these external slopes, which are not very steep, the deposits are rapidily covered by local sedimentation or by subsequent volcanism. In addition, manganese deposits are rarely found because the plumes ascend much higher than the local elevation of the walls bordering the valley and are carried away by local currents.

On the contrary, on a slow spreading ridge like the MidAtlantic Ridge (MAR), fossil and active fields are much less geographically separated and indeed may occur at the same site; moreover, the rift valley is confined by walls of more than a thousand meters in height, thus partly blocking the escape of hydrothermal emanations. These slow spreading ridges are the best place to obtain a record of past activity on an areal scale compatible with the range of a manned submersible.

The TAG field, at $26^{\circ} \mathrm{N}$ on the MAR was studied as early as 1972 [Rona 1973] as a part of the Trans-Atlantic Geotraverse project. In 1985 a dredge haul recovered sulfide deposits, some

\footnotetext{
${ }^{1}$ Centre des Faibles Radioactivités, CNRS-CEA, Gif sur Yvette,

${ }^{2}$ Woods Hole Oceanographic Institution, Woods Hole, Massachu-

3Ifremer-Brest Plouzané, France.

${ }^{4}$ National Oceanic and Atmospheric Administration, Miami, Florida
} France. setts.

Copyright 1993 by the American Geophysical Union.

Paper number 92JB01898.

$0148-0227 / 93 / 92 J B-01898 \$ 05.00$ of them being associated with aragonite, and black smokers were imaged [Rona et al., 1986]. Three Alvin dives were then conducted in 1986 to sample active chimneys and fossil sulfide deposits [Thompson et al., 1988]. Some of these samples have been dated [Lalou et al., 1986, 1990]. These dives were followed at the beginning of 1990 by 16 new Alvin dives which extensively sampled both the active mound and nearby relict sulfide mounds [MAR Hydrothermal Research Team, 1991] to obtain a more representative sampling. The total area of the TAG hydrothermal field is at least $25 \mathrm{~km}^{2}$.

Three hundred kilometers to the south, separated from the TAG field by the Kane fracture zone (Figure 1), the Snakepit hydrothermal field was discovered during Ocean Drilling Program (ODP) leg 106 [Scientific Party Leg 106, 1986a,b]. Four Alvin dives, one in 1986 [Thompson et al., 1988; Lalou et al., 1990] and three more in 1990 (following the TAG dives) were made. Also 11 Nautile dives were made in 1988 [Mevel et al., 1989]; thus this site is also now extensively sampled for hydrothermal deposits. Compared to TAG, it has a considerably smaller areal extent of about $0.45 \mathrm{~km}^{2}$.

In this paper, we present new age data on samples recovered by Alvin in 1990 at TAG and Snakepit and by Nautile at Snakepit. This allows the reconstruction of 125,000 years of hydrothermal activity at TAG and 4000 years at Snakepit. A comparison between the activity at the two fields is now possible, as well as a comparison with the $21^{\circ} \mathrm{N}$ and $13^{\circ} \mathrm{N}$ EPR fields on a faster spreading ridge.

\section{Radiochronological Methods, PRINCIPLeS AND LMMTATIONS}

The methods, schematically presented in Figure 2, have been described in detail by Lalou and Brichet [1987]. We do not outline the chemical procedure here but describe only the principles and limitations.

For recent samples (younger than about 200 years), we use the $210 \mathrm{~Pb} / \mathrm{Pb}$ method in which it is assumed that lead 210 and stable lead are precipitated from the hydrothermal fluid derived from water-rock interactions and that when they formed, the 


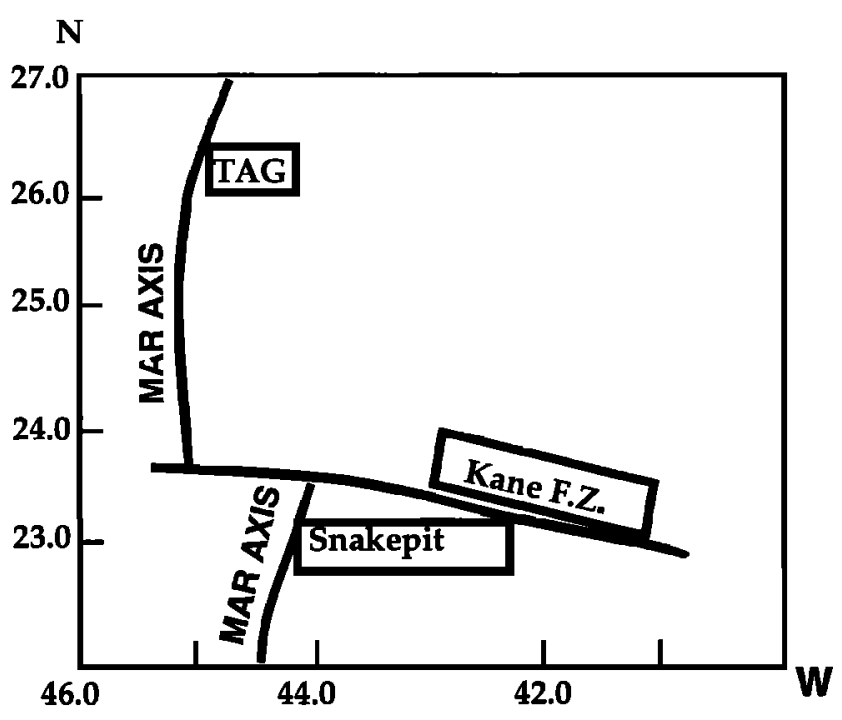

Fig. 1. Topographic sketch of the Mid-Atlantic Ridge $22^{\circ}$ to $27^{\circ} \mathrm{N}$ showing the position of the two studied hydrothermal fields on the ridge and the offset of the MAR axis at the Kane Fracture Zone.

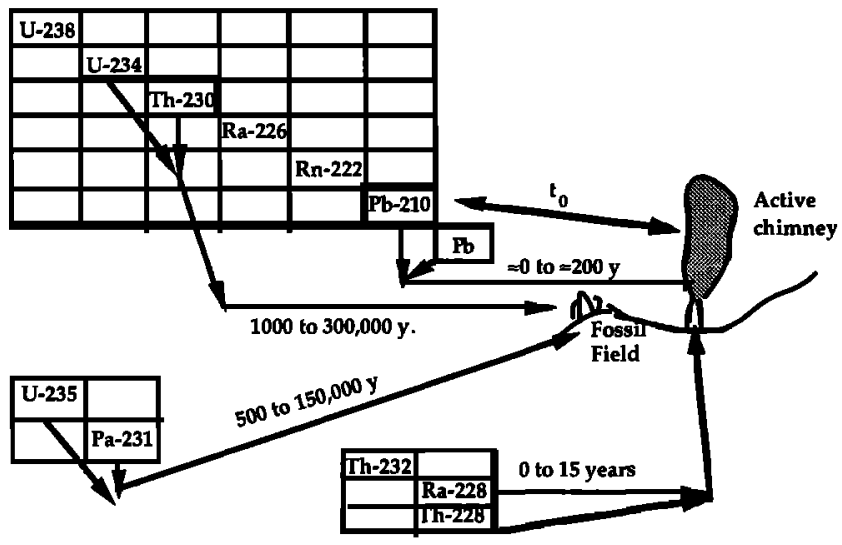

Fig. 2. The different methods for dating recent and fossil hydrothermal deposits.

chimneys included lead 210 and stable lead in the same ratio as the one measured in the particles filtered from the present day plume. This also implies that this ratio has remained essentially the same in the field during the recent activity. As far as possible, this was verified on the EPR $13^{\circ} \mathrm{N}$ field where the plumes were sampled periodically from 1982 to 1987. This ratio must be measured in each field because it varies from one site to the other [Lalou et al., 1991].

All results must be corrected for decay between sampling and analysis time. When plume particles are not available, the initial ratio may be obtained if some samples have $228 \mathrm{Ra}$ from ${ }^{228} \mathrm{Th} / 228 \mathrm{Ra}$ which allows a cross-check of the age obtained by $210 \mathrm{~Pb} / \mathrm{Pb}$.

When the samples have very low $210 \mathrm{~Pb} / \mathrm{Pb}$ ratios giving ages $>200$ years, the $230 \mathrm{Th} / 234 \mathrm{U}$ method is used. This method is usually applied to samples having ages between 5000 and 350,000 years, but by using large quantities of samples and long counting times, it is possible to lower the 5000 year limit to about 1000 years. Geochemically, this method requires that uranium enters the sulfides from seawater or from hydrothermal fluid during precipitation, that no thorium enters, and that no exchange has taken place between the time of sulfide formation and the time of sampling. Two indicators may confirm that this closed system hypothesis is fulfilled; first, when the thorium fraction is free of $232 \mathrm{Th}$; second, when the ${ }^{23}{ }^{1} \mathrm{~Pa} / 235 \mathrm{U}$ dating technique may be applied and gives a concordant age. When a low 232Th activity is measured, the age obtained must be considered as a maximum age.

In addition, in the TAG hydrothermal field some aragonite precipitates have been recovered, and ${ }^{14} \mathrm{C}$ dates have been obtained using accelerator mass spectrometry (AMS) on minute samples and compared to ${ }^{230} \mathrm{Th} / 234 \mathrm{U}$ dates [Lalou et al., 1990].

\section{Results}

New analytical results are given in Tables $1 \mathrm{a}$ and $1 \mathrm{~b}$ for recent samples (taken from active chimneys), and Tables 2 a and $2 b$ for fossil ones. Previously published data are not tabulated here but are used in summary figures.

\section{$210 \mathrm{~Pb} / \mathrm{Pb}$ at the Onset of Precipitation}

In our previous study [Lalou et al., 1990] we did not have particles filtered from the fluid to measure the $210 \mathrm{~Pb} / \mathrm{Pb}$ ratio at the onset of precipitation, so we used the highest ratio found in chimney samples. These were $1.39 \pm 0.14$ and $1.17 \pm 0.09$ for TAG and Snakepit, respectively. During the 1990 Alvin expedition, particulate matter was filtered from the plume of active chimneys at both sites giving $210 \mathrm{~Pb} / \mathrm{Pb}$ ratios of respectively $1.23 \pm 0.11$ (TAG sample F2) and $1.32 \pm 0.13$ (Snakepit sample F3). For both sites, the difference with the ratios used previously is within statistical errors, so we do not need to correct the ages already published.

\section{TAG Field (Tables 1a and 2a)}

Figure 3 is a map of the hydrothermal field. It extends from the presently active black smokers, near the boundary between the rift valley and the eastern wall of the valley, to the top of the valley about $10 \mathrm{~km}$ away, where manganese oxides were recovered. Approximately halfway between the active mound and the manganese oxides, another mound of fossil sulfides has been discovered and sampled.

Figure 4 is a summary of the dates obtained, for the presently active mound, using both new and previously published data.

The sulfides from the presently active fields are younger than 50 years while the talus samples recovered either by dredging or by Alvin are older than 4000 years. Moreover, different episodes of activity have been established from the dredged samples, at 26,000-18,000 years, 16,000-14,000 years, 11,500-9500 years and 4500-4,000 years. Some are associated with aragonitic deposits which have been shown to be characteristic of normal low-temperature Atlantic deep sea water $\left(\delta^{18} \mathrm{O}=+4.0\right.$ to $+4.4 \%$ versus. Pee Dee Belemnite standard (PDB) and $\delta^{13} \mathrm{C}$ between +2.5 and $+3.7 \%$ ), thus necessitating a total cooling of the mound between activities.

Dive A 2188 (Figure 5), on a newly discovered relict sulfide mound, recovered one sample (3) as old as 102,000 years at the base of the mound, and a 9400 year sample (6) at the top. On the same relict mound, dive A 2195 recovered a sample (1) dated at 50,000 years. These data imply intermittent activity at this site for over 100,000 years. During dive 2188 , a powdery 
TABLE 1a. Analytical Results for TAG Recent Samples

\begin{tabular}{|c|c|c|c|c|c|}
\hline No. & Mineralogy & $\begin{array}{r}\mathrm{Pb}, \\
\mathrm{ppm}\end{array}$ & $\begin{array}{l}\text { Pb210*, } \\
\text { dpm/g }\end{array}$ & $\begin{array}{l}\mathrm{Pb} 210 / \mathrm{Pb} \\
\mathrm{dpm} / \mu \mathrm{g}\end{array}$ & $\begin{array}{l}\text { Age } \\
\text { years }\end{array}$ \\
\hline $\begin{array}{l}\text { A2191 F2 Particles } \\
\text { Chimneys from which the par- } \\
\text { ticules have been filtered } \\
\text { A2181-1-1 AD1 } \\
\text { A2181-1-1-AD (intermediate) } \\
\text { A2179-4-1AD } \\
\text { A2179-4-1AD2 }\end{array}$ & $\mathbf{A}, \mathrm{Ch}, \mathbf{P}$ & $\begin{array}{l}38.2 \pm 3.8 \\
20.9 \pm 2 \\
16.9 \pm 0.8\end{array}$ & $\begin{array}{c}40.6 \pm 2.1 \\
24.8 \pm 1.6 \\
18.5 \pm 0.9\end{array}$ & $\begin{array}{l}1.063 \pm 0.12 \\
1.19 \pm 0.14 \\
1.095 \pm 0.077\end{array}$ & $\begin{array}{r}<9 \\
0 \\
<7\end{array}$ \\
\hline $\begin{array}{l}\text { Outer } \\
\text { Intermediate }\end{array}$ & $\begin{array}{l}\mathrm{Ch}, \mathrm{A} \\
\mathrm{A}, \mathrm{Ch}\end{array}$ & $\begin{array}{c}11.1 \pm 1.1 \\
4.0 \pm 0.4\end{array}$ & $\begin{array}{l}14.9 \pm 0,8 \\
4.7 \pm 0.25\end{array}$ & $\begin{array}{l}1.34 \pm 0.15 \\
1.17 \pm 0.13\end{array}$ & $\begin{array}{l}0 \\
0\end{array}$ \\
\hline
\end{tabular}

A, anhydrite; P,pyrite; Ch,chalcopyrite. Minerals are indicated in decreasing abundance.

* The quoted uncertainty is one standard deviation. Values are recalculated to the date of sampling. dpm, disintegrations per minute.

TABLE 1b. Analytical Results for Snakepit Recent Samples

\begin{tabular}{|c|c|c|c|c|c|c|c|c|}
\hline A2194-F3 & Mineralogy & \multicolumn{2}{|c|}{$\begin{array}{c}\text { Pb, } \\
\text { ppm }\end{array}$} & \multicolumn{2}{|c|}{$\begin{array}{l}\mathrm{Pb} 210^{*} \\
\mathrm{dpm} / \mathrm{g}\end{array}$} & \multicolumn{2}{|c|}{$\begin{array}{c}\mathrm{Pb} 210 / \mathrm{Pb} \\
\mathrm{dpm} / \mu \mathrm{g}\end{array}$} & \multirow[t]{2}{*}{$\begin{array}{l}\text { Age, } \\
\text { years }\end{array}$} \\
\hline & & & & & & & & \\
\hline Particles & & 395 & \pm 32 & 523 & \pm 30 & 1.32 & \pm 0.13 & \\
\hline \multicolumn{9}{|c|}{ The Beehive } \\
\hline \multicolumn{9}{|l|}{ Top } \\
\hline A2194-1-1AD(1) & $\mathrm{P}, \mathrm{Ch}$ & 380 & \pm 20 & 500 & \pm 40 & 1.31 & \pm 0.12 & $<4$ \\
\hline A2194-1-1AD (4) & $\mathrm{A}, \mathrm{Gy}, \mathrm{Ch}$ & 48 & \pm 2.5 & 57 & \pm 5 & 1.19 & \pm 0.12 & $<7$ \\
\hline HS05-04 & $\mathrm{Ch}, \mathrm{S}, \mathrm{L}, \mathrm{G}$ & 357 & \pm 35 & 444 & \pm 29 & 1.24 & \pm 0.14 & $<7$ \\
\hline HS10-01(2) & S,Ch,Pyr,G & 868 & \pm 43 & 1113 & \pm 65 & 1.28 & \pm 0.10 & $<5$ \\
\hline HS10-02 & S,L,Ch,G,P,M & 520 & \pm 52 & 614 & \pm 36 & 1.18 & \pm 0.14 & $<8$ \\
\hline HS11-01(1) & $\mathrm{Ch}, \mathrm{L}, \mathrm{G}$ & 8.2 & $\pm \quad 0.8$ & 9.6 & $\pm \quad 0.5$ & 1.17 & \pm 0.13 & $<8$ \\
\hline HS 11-01(3) & & 250 & \pm 12 & 292 & \pm 13 & 1.17 & \pm 0.08 & $<7$ \\
\hline HS11-02 & $\mathrm{S}, \mathrm{Ch}, \mathrm{L}, \mathrm{G}$ & 75 & \pm 4 & 86 & $\pm \quad 4$ & 1.15 & \pm 0.08 & $<8$ \\
\hline \multicolumn{9}{|l|}{ Base } \\
\hline HSO3-02 int & $\mathrm{P}, \mathrm{M},(?)$ & 95 & \pm 5 & 31.1 & $\pm \quad 1.8$ & 0.327 & \pm 0.025 & $44 \pm 4$ \\
\hline HSO3-03(2) & $\mathbf{S , P}, \mathbf{M}$ & 2065 & \pm 100 & 2391 & \pm 114 & 1.16 & \pm 0.08 & \pm 4 \\
\hline HSO3-03(3) & $\mathrm{L}, \mathrm{Ch}$ & 82 & \pm 5 & 102.7 & $\pm \quad 5.5$ & 1.25 & \pm 0.09 & $<5$ \\
\hline HSO3-03(4) & $\mathbf{L}, \mathrm{Ch}$ & 250 & \pm 12 & 293 & \pm 7 & 1.17 & \pm 0.09 & $<8$ \\
\hline HS03-04 ext & $\mathrm{L}, \mathrm{G}, \mathrm{Ch}, ;(?)$ & 231 & \pm 11 & 291 & \pm 16 & 1.26 & \pm 0.09 & $<5$ \\
\hline HS03-04 int & $\mathrm{L}, \mathrm{B}, \mathrm{Ch}, \mathrm{P}, \mathrm{M}, \mathrm{G}$ & 317 & \pm 16 & 396 & \pm 19 & 1.25 & \pm 0.09 & $<5$ \\
\hline HS05-03(B2) ext & & 78 & \pm 9 & 0.417 & $\pm \quad 0.036$ & 0.0023 & \pm 0.00022 & $201 \pm 5 ?$ \\
\hline HS05-03(B2) int. & $\mathbf{P}, \mathbf{M}, \mathrm{Ch}$ & 148 & \pm 7 & 0.060 & 0.011 & 0.0004 & \pm 0.00007 & $256 \pm 7 ?$ \\
\hline HS05-03(C) & & 119 & \pm 6 & 0.146 & 0.007 & 0.00122 & \pm 0.00008 & $221 \pm 4 ?$ \\
\hline HSO5-05 & $\mathrm{P}, \mathbf{M}$. & 119 & \pm 6 & 12.1 & 0.7 & 0.102 & \pm 0.008 & $81 \pm 4$ \\
\hline HSO5-06 & A & 8.8 & $\pm \quad 0.9$ & 9.6 & $\pm \quad 0.6$ & 1.093 & \pm 0.13 & $<6$ \\
\hline HS10-03 & & 581 & \pm 29 & 697 & \pm 47 & 1.20 & $\pm 0,10$ & $<7$ \\
\hline HS10-04 & $\mathrm{P}, \mathrm{M}, \mathrm{Ch}$ & 116 & \pm 6 & 122 & \pm 6 & 1.052 & \pm 0.07 & $7 \pm 4$ \\
\hline HS10-05 & & 27 & \pm 6 & 138 & \pm & 1.087 & \pm 0.072 & $6 \pm 4$ \\
\hline \multicolumn{9}{|c|}{ The Moose } \\
\hline HS03-01ext & $\mathbf{B}, \mathbf{P}, \mathbf{M}$ & 3985 & \pm 200 & 5640 & \pm 308 & 1.41 & \pm 0.10 & $<4$ \\
\hline HSO3-01 int & S,L,Ch,G & 340 & \pm 17 & 480 & \pm 25 & 1.41 & \pm 0.10 & $<4$ \\
\hline \multicolumn{9}{|c|}{ The Cliff (The Nail) } \\
\hline HS08-01 & $\mathrm{S}, \mathrm{Ch}, \mathrm{L}, \mathrm{G}$ & 906 & \pm 45 & 1087 & \pm 75 & 1.20 & \pm 0.10 & $<7$ \\
\hline HS06-07 & $\mathrm{L}, \mathrm{G}, \mathrm{Ch}$ & 256 & \pm 25 & 363 & \pm 24 & 1.42 & \pm 0.17 & $<5$ \\
\hline HSO8-02 & S,L,Ch,P,G,M & 477 & \pm 24 & 540 & \pm 33 & 1.13 & \pm 0.09 & $<9$ \\
\hline HS10-06(1) & & 1298 & \pm 65 & 1677 & \pm 73 & 1.292 & \pm 0.086 & $<4$ \\
\hline HS10-06(2) & & 1313 & \pm 65 & 1629 & \pm 66 & 1.241 & \pm 0.080 & $<6$ \\
\hline HS11-05 & & 147 & \pm 7 & 85 & \pm 5 & 0.58 & \pm 0.04 & $26 \pm 4$ \\
\hline
\end{tabular}

M, marcassite; A, anhydrite; P, pyrite, Gy, gypsum; Ch, chalcopyrite; G, goethite; S, sphalerite; L, lepidocrocite; Pyr, pyrrhotite. Minerals are indicated in decreasing abundance.

*The quoted uncertainty is one standard deviation and values are calculated at the date of sampling. 
TABLE 2a. Analytical Results for TAG Fossil Samples

\begin{tabular}{|c|c|c|c|c|c|c|c|}
\hline No. & $\begin{array}{l}\text { U 238, } \\
\text { ppm }\end{array}$ & $\begin{array}{l}\mathrm{U} 234, \\
\mathrm{dpm} / \mathrm{g}\end{array}$ & $\begin{array}{c}\text { 234/238, } \\
\text { Activ Ratio }\end{array}$ & $\begin{array}{c}\text { Th 232, } \\
\text { ppm }\end{array}$ & $\begin{array}{l}\text { Th 230, } \\
\text { dpm/g }\end{array}$ & $\begin{array}{l}\text { 230/234, } \\
\text { Act. Ratio }\end{array}$ & $\begin{array}{c}\text { Age Th } 230 \\
10^{3} \text { years }\end{array}$ \\
\hline $\begin{array}{l}2183-6-2 \\
2188-3-1 \\
2188-6-1-A \\
2195-1-1 \\
2188-\end{array}$ & $\begin{array}{c}15.85 \pm 1.06 \\
4.84 \pm 0.130 \\
0.04 \pm 0.0014 \\
0.27 \pm 0.007\end{array}$ & $\begin{array}{c}13.43 \pm 0.90 \\
4.05 \pm 0.11 \\
0.03 \pm 0.01 \\
0.23 \pm 0.006\end{array}$ & $\begin{array}{l}1.152 \pm 0.008 \\
1.138 \pm 0.008 \\
1.148 \pm 0.040 \\
1.136 \pm 0.025\end{array}$ & $\begin{array}{l}<0.0004 \\
<0.004 \\
0.007 \pm 0.003 \\
<0.0015\end{array}$ & $\begin{array}{l}1.19 \pm 0.05 \\
2.51 \pm 0.08 \\
0.003 \pm 0.0003 \\
0.085 \pm 0.002\end{array}$ & $\begin{array}{l}0.088 \pm 0.007 \\
0.620 \pm 0.025 \\
0.084 \pm 0.009 \\
0.372 \pm 0.012\end{array}$ & $\begin{array}{c}10 \pm 1 \\
102 \pm 7 \\
9.4 \pm 1.3 \\
50 \pm 2\end{array}$ \\
\hline (Mn oxide) & $\begin{array}{l}4.21 \pm 0.18 \\
3.98 \pm 0.24\end{array}$ & $\begin{array}{l}3.37 \pm 0.13 \\
2.96 \pm 0.18\end{array}$ & $\begin{array}{l}1.088 \pm 0.054 \\
1.013 \pm 0.075\end{array}$ & $\begin{array}{l}<0.018 \\
<0.06\end{array}$ & $\begin{array}{l}2.50 \pm 0.125 \\
2.91 \pm 0.78\end{array}$ & $\begin{array}{l}0.743 \pm 0.048 \\
0.981 \pm 0.084\end{array}$ & $\begin{array}{l}140 \pm 20 \\
>400\end{array}$ \\
\hline
\end{tabular}

The quoted uncertainty is one standard deviation.

TABLE $2 b$. Analytical Results for Snakepit Fossil Samples

\begin{tabular}{|c|c|c|c|c|c|c|c|}
\hline No. & $\begin{array}{l}\text { U 238, } \\
\text { ppm }\end{array}$ & $\begin{array}{l}\text { U 234, } \\
\text { dpm/g }\end{array}$ & $\begin{array}{l}\text { 234/238, } \\
\text { Act. Ratio }\end{array}$ & $\begin{array}{c}\text { Th 232, } \\
\text { ppm }\end{array}$ & $\begin{array}{c}\text { Th 230, } \\
\text { dpm/g }\end{array}$ & $\begin{array}{l}\text { 230/234, } \\
\text { Act. Ratio }\end{array}$ & $\begin{array}{c}\text { Age Th } 230 \\
10^{3} \text { years }\end{array}$ \\
\hline \multicolumn{8}{|c|}{ Beehive } \\
\hline HSO5-03 B(2) & $0.57 \pm 0.05$ & $0.44 \pm 0.04$ & $1.065 \pm 0.039$ & $0.009 \pm 0.003$ & $0.009 \pm 0.001$ & $0.019 \pm 0.003$ & $2 \pm 0.35$ \\
\hline HS05-03 C & $0.29 \pm 0.08$ & $0.25 \pm 0.01$ & $1.153 \pm 0.024$ & $0.006 \pm 0.002$ & $0.006 \pm 0.001$ & $0.023 \pm 0.003$ & $2.5 \pm 0.35$ \\
\hline \multicolumn{8}{|c|}{ Firtree } \\
\hline HS05-01 & $3.86 \pm 0.23$ & $2.98 \pm 0.18$ & $1.048 \pm 0.026$ & $<0.017$ & $0.058 \pm 0.008$ & $0.019 \pm 0.003$ & $2.1 \pm 0.35$ \\
\hline HSO5-02 & $0.32 \pm 0.01$ & $0.27 \pm 0.01$ & $1.146 \pm 0.050$ & $0.005 \pm 0.003$ & $0.009 \pm 0.001$ & $0.033 \pm 0.005$ & $3.6 \pm 0.6$ \\
\hline A2193-4-1 & $0.69 \pm 0.03$ & $0.59 \pm 0.02$ & $1.160 \pm 0.027$ & $<0.0018$ & $0.015 \pm 0.001$ & $0.025 \pm 0.003$ & $2.8 \pm 0.3$ \\
\hline \multicolumn{8}{|c|}{ The Cliff } \\
\hline A2193-6-1 & $2.68 \pm 0.06$ & $2.24 \pm 0.05$ & $1.131 \pm 0.017$ & $<0.002$ & $0.018 \pm 0.0017$ & $0.008 \pm 0.0008$ & $0.875 \pm 0.1$ \\
\hline HSO6-05 & $0.37 \pm 0.02$ & $0.31 \pm 0.01$ & $1.151 \pm 0.048$ & $0.01 \pm 0.003$ & $0.012 \pm 0.001$ & $0.038 \pm 0.003$ & $4.2 \pm 0.6$ \\
\hline HS06-06 & $1.05 \pm 0.04$ & $0.87 \pm 0.03$ & $1.123 \pm 0.028$ & $0.004 \pm 0.003$ & $0.026 \pm 0.002$ & $0.030 \pm 0.002$ & $3.25 \pm 0.25$ \\
\hline A2193-5-1 & $3.29 \pm 0.17$ & $2.86 \pm 0.14$ & $1.170 \pm 0.02$ & $<0.003$ & $0.095 \pm 0.003$ & $0.033 \pm 0.002$ & $3.7 \pm 0.45$ \\
\hline HS11-03 & $0.63 \pm 0.04$ & $0.51 \pm 0.03$ & $1.090 \pm 0.07$ & $<0.0007$ & $0.015 \pm 0.003$ & $0.030 \pm 0.006$ & $3.4 \pm 0.60$ \\
\hline \multicolumn{8}{|c|}{ Stockwork } \\
\hline HS11-06 & $0.75 \pm 0.07$ & $0.62 \pm 0.05$ & $1.135 \pm 0.089$ & $0.059 \pm 0.027$ & $0.013 \pm 0.005$ & $0.021 \pm 0.008$ & $2.5 \pm 0.9$ \\
\hline HS11-08 & $0.09 \pm 0.01$ & $0.07 \pm 0.01$ & $1.029 \pm 0.056$ & $0.002 \pm 0.001$ & $0.002 \pm 0.0001$ & $0.026 \pm 0.005$ & $2.85 \pm 0.5$ \\
\hline HS16-05 & $13.70 \pm 0.62$ & $10.50 \pm 0.47$ & $1.044 \pm 0.037$ & $0.043 \pm 0.03$ & $11.312 \pm 0.68$ & $1.076 \pm 0.081$ & $>350$ \\
\hline
\end{tabular}

The quoted uncertainty is one standard deviation.

manganese oxide deposit (4) was sampled from which we have separated hard plates of Mn giving an age of 140,000 $\pm 20,000$ years, in agreement with the old age of this relict hydrothermal mound. Another subsample of this same Mn-oxide deposit gives an age of around 400,000 years. However, this subsample is extremely friable and contains an insoluble phase; we suspect this may represent a maximum age because of pollution with Th from a sedimentary component.

Higher on the wall, only thick layers of manganese oxide have been recovered and previously dated; they also show a discontinuous activity, with activity pulses around 15,000 and 7000 years, and scattered dates at about 30,000, 47,000, 100,000 and 125,000 years [Lalou et al., 1986].

Figure 6 gives a cross section of the total extension of the hydrothermal field with a summary of the ages.

\section{Snakepit Field (Tables $1 b$ and $2 b$ )}

The Snakepit hydrothermal field (Figures $7 a$ and $7 b$ ) is located on a neovolcanic ridge with an axial graben limited by two horsts within which the hydrothermal activity was found. Geologic, geophysical and topographic characteristics are given by Karson et al.. [1987], Thompson et al.. [1988] and Mevel et al. [1989].

In the TAG area, the present-day activity is found on about 100,000 years basement (based on the spreading rate calculated from magnetic anomalies), whereas the Snakepit activity is located in the central part of the axial graben in the neovolcanic zone $(<5000$ years)

Figure $7 b$ shows the areal extension of hydrothermal manifestation. The French Nautile team has named the place of the main present day activity "La Ruche" (The Beehive) which is located on the eastern ridge and also has, lower on its eastern flank, another active vent "L'Elan" (The Moose). On the central ridge, a quite extinct site where only diffuse water

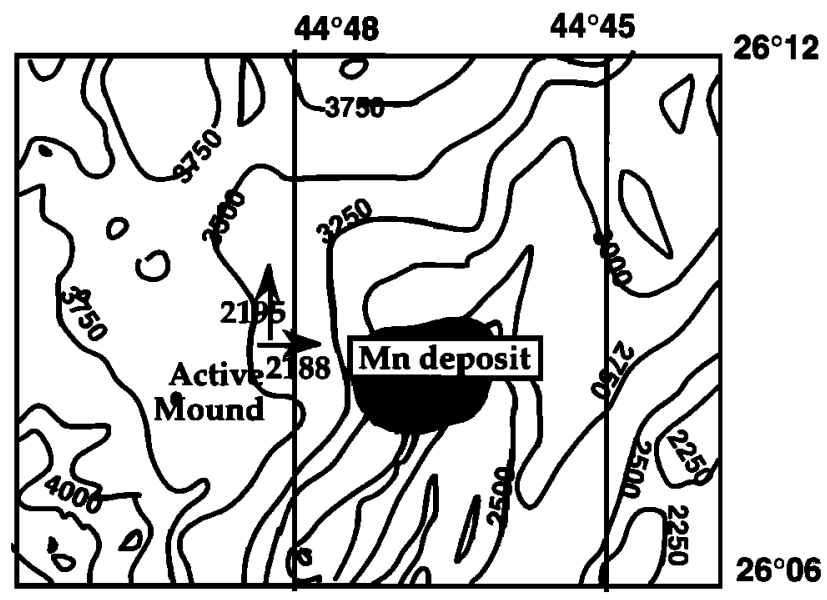

Fig. 3. Topographic map of the TAG hydrothermal field with the position of the different areas where samples have been collected. 


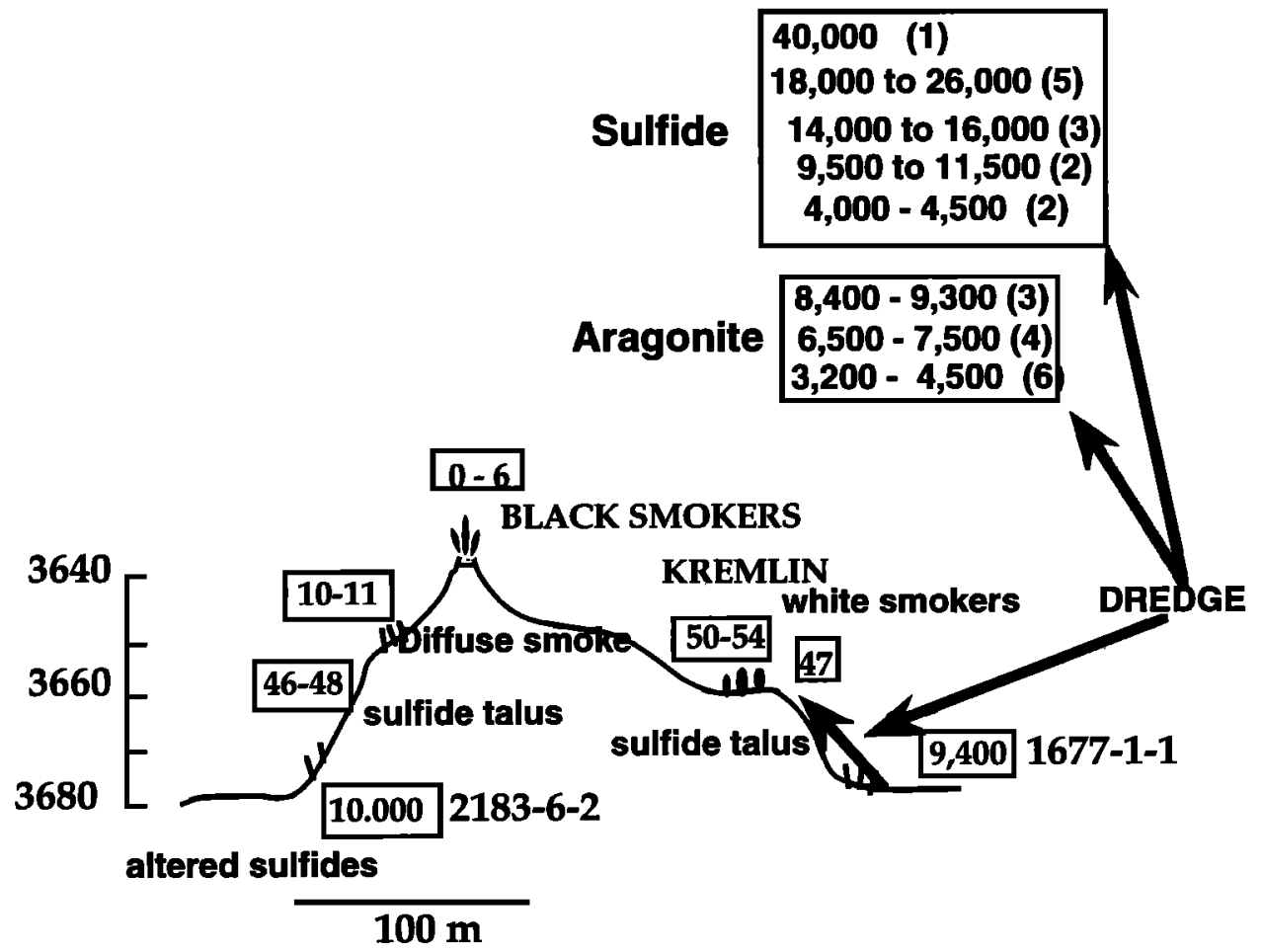

Fig. 4. Schematic cross section of the TAG hydrothermal mound with a summary of the ages. Some characteristic samples with their ages are given in the inserts.

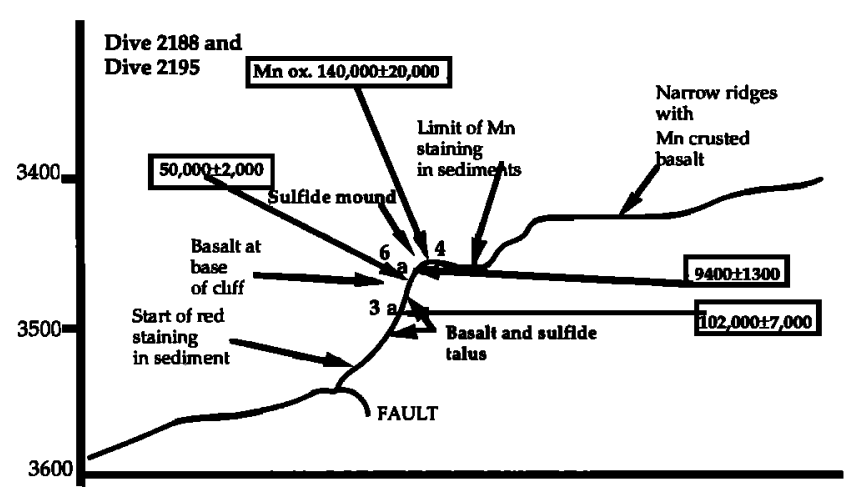

Fig. 5. Cross section of the eastern wall of the MAR between 3600 and $3400 \mathrm{~m}$ depth covered by ALVIN dives A 2188 and A 2195 on a relict sulfide mound, showing the position of the dated samples and of the diverse deposits.

escapes was called "Le Sapin" (The Firtree), and on the eastern face of the western ridge is a sulfide talus called "La Falaise" (The Cliff). A fault has uncovered an outcrop of stockwork in the higher part of the Cliff, while an active chimney "Le Clou" (The Nail) and other actively diffusing areas are found at the base of the Cliff [Mevel et al., 1989].

Dating results are presented in Figure 8 on a schematic cross section. The representative sampling strategy has allowed a chronological history to be defined for the first time for the Snakepit field.

The Beehive Site. Three groups of samples were collected. The first group is from the active top of the mound. It is mainly represented by samples of active beehive structures, or inactive but still vertical chimneys. They are primarily made of dominant pyrrhotite associated with various amounts of chalcopyrite (core of the chimneys) and sphalerite (outer part). Pyrrhotite is very rapidily oxidized into lepidocrocite and goethite. Anhydrite is only abundant within the chimney walls. Samples A 2194-1-1A to D are different parts of a sample taken from the wall of the chimney from which particles were filtered from the plume. The internal part of the wall (subsample 4) containing anhydrite has been dated at $<7$ years; one sample from the external layer (subsample 1) gives an age of $<4$ years. All other samples in this group from the active top of the Beehive have ages near zero. This confirms the dates obtained for two samples from this locality during the 1986 Alvin dive (A 1683-1 and A 1683-4) which also gave ages around zero.

The second group is from the talus around and between the vertical active chimneys. The samples are fragments from the beehive edifice with the same mineralogy (but higher oxidation), and breccias of pyrite (HS 10-04). Ages of between 0 and 44 years were found for these samples.

The third group is from the base of the sulfide mound, about $10 \mathrm{~m}$ downslope. These samples are mainly massive pyrite and pyrite-chalcopyrite. The dating of sample HS 05-03 is unclear: ${ }^{210} \mathrm{~Pb} / \mathrm{Pb}$ gives ages between 200 and 260 years which are at the upper limit of this method (Table $1 b$ ) while ${ }^{230} \mathrm{Th} /{ }^{234} \mathrm{U}$ gives ages between 1650 and 2800 years, at the lower limit of the method (Table $2 b$ ). The real age of this sample is probably in between the limits of both methods: whereas a slight contamination by exogeneous (oceanic) $210 \mathrm{~Pb}$ would be critical for relatively old samples, giving a too young apparent age, a contamination by exogeneous ${ }^{230} \mathrm{Th}$ (indicated by possible ${ }^{232} \mathrm{Th}$ presence) gives a too old apparent age. One of these artefacts may be responsible for this unconformity. But, as the outer part of the sample, measured by $210 \mathrm{~Pb} / \mathrm{Pb}$ method, gives an age younger than the internal part, this one being practically out of the limit of the 


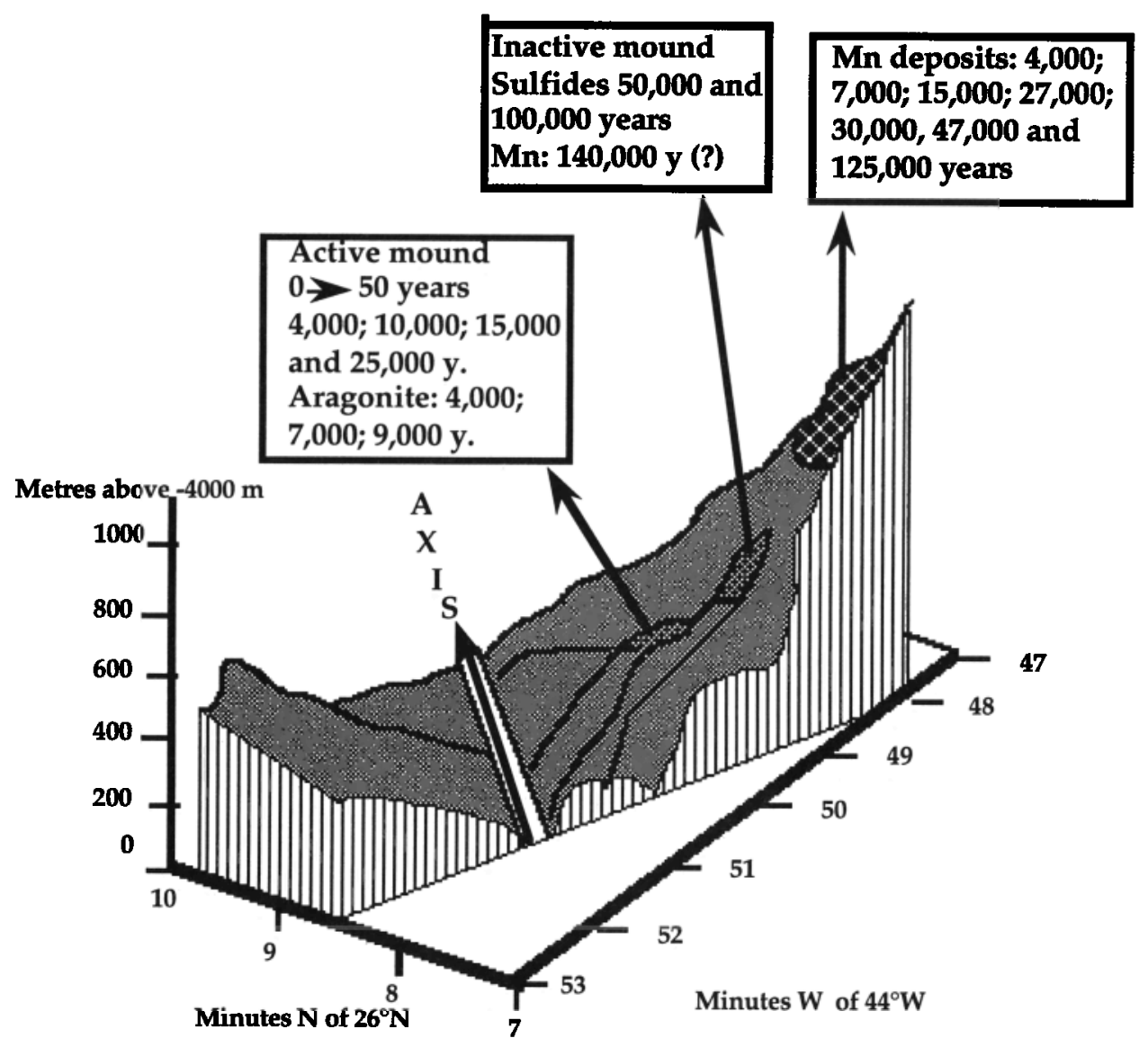

Fig. 6. Schematic cross section of the entire hydrothermal field at TAG summarizing the chronology of the eastern wall.

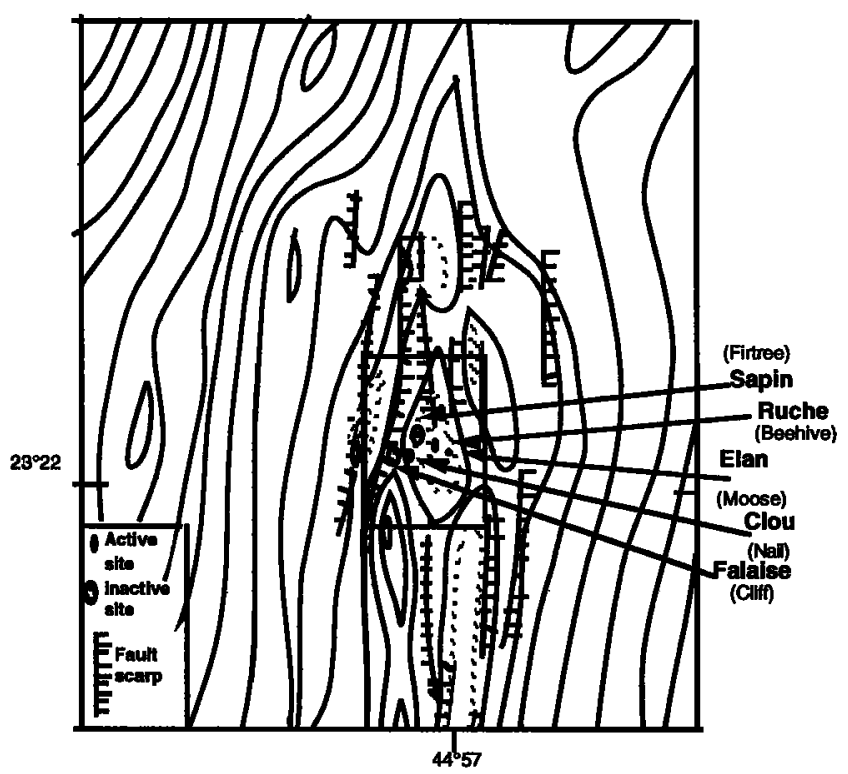

Fig. 7a . Topographic map of the Snakepit hydrothermal field [after Mevel et al.,1989]. The central rectangle encompassing the hydrothermal field is detailed in figure $7 \mathrm{~b}$.

method, we prefer to keep the ages given by ${ }^{230} \mathrm{Th} / 234 \mathrm{U}$ which are identical, within errors, for the two subsamples. Moreover, the sample position on an in situ outcrop on a scarp at the very foot of the mound induces us to think that it is probably one of the older samples of the group and belongs with the fossil sulfides. Sample HS 05-05 is a boulder from the pyrite mound but closer to the top of the mound.

At this site, the ages apparently increase with depth of occurence of the samples on the mound.

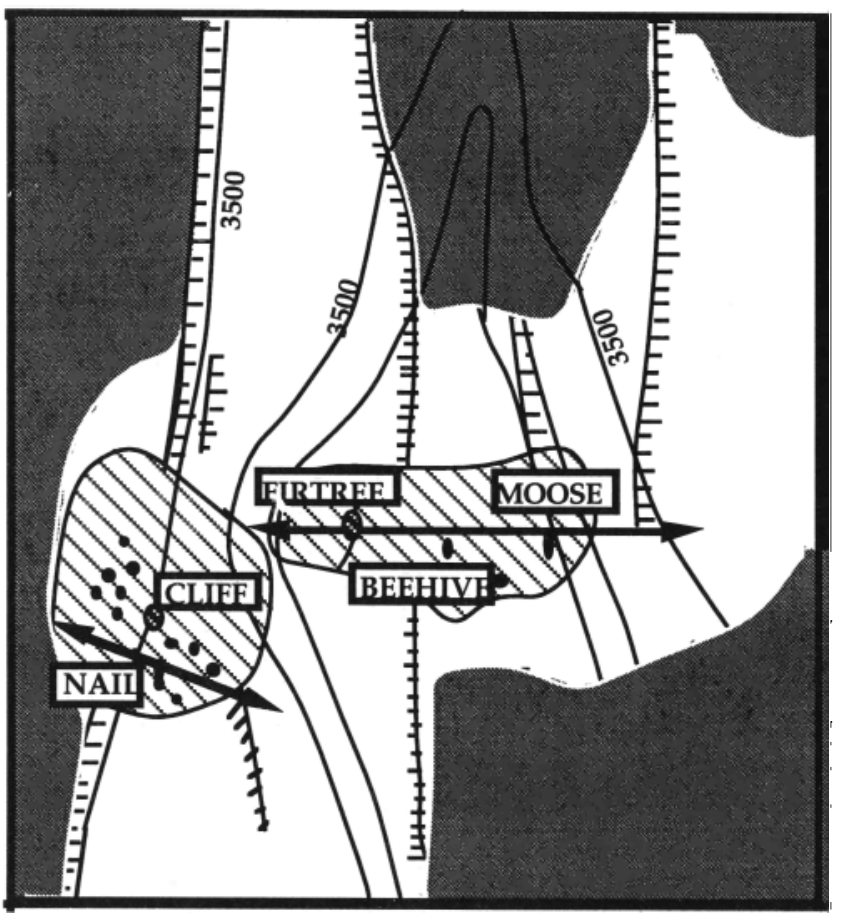

Fig. 7b. Detail of the Snakepit field. The two lines represent the path along which the cross sections of Figure 8 have been drawn. Hatched area is the hydrothermal deposits; gray area is pillow basalts. 


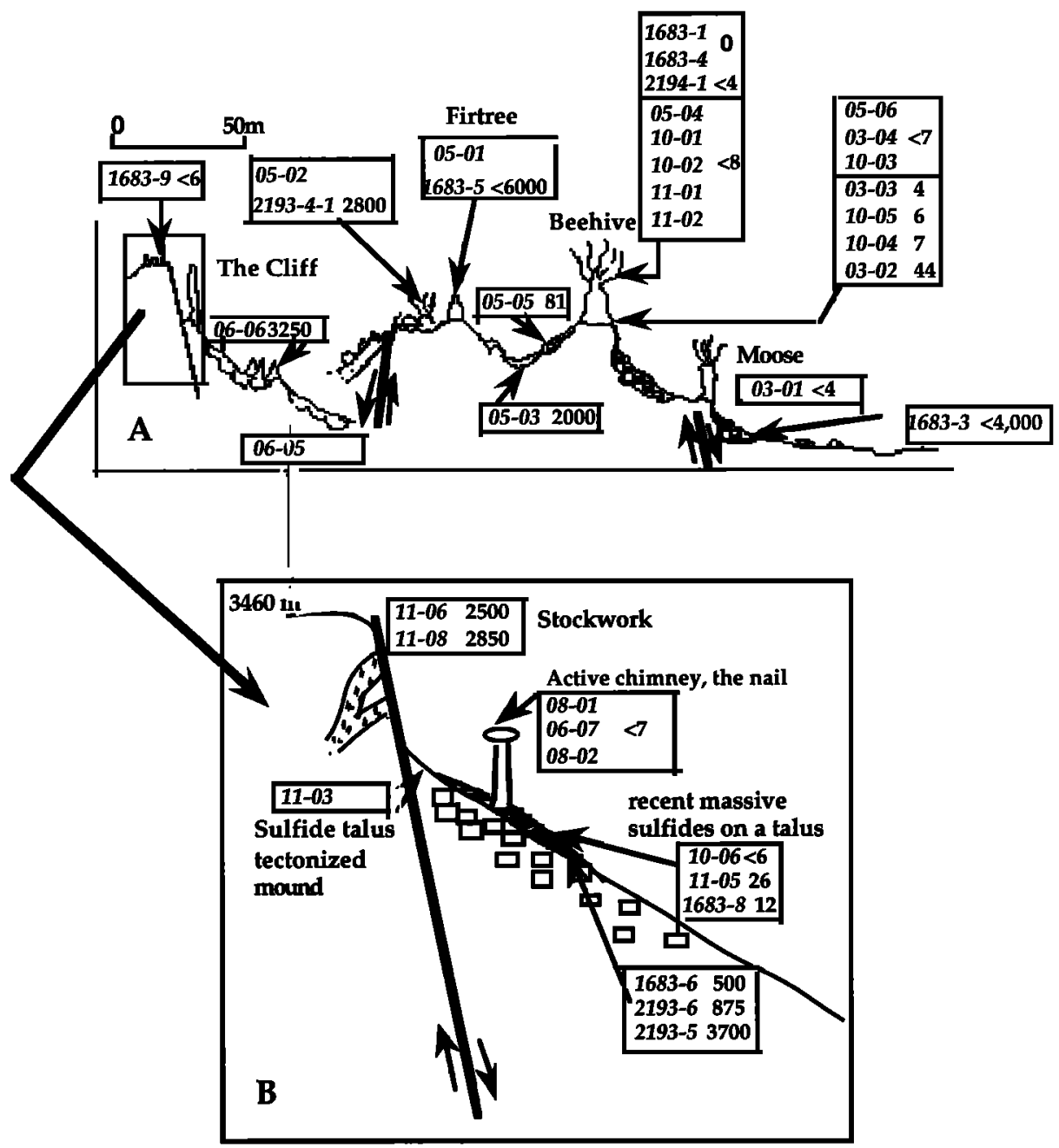

Fig. 8. Schematic cross section of the Snakepit field with the positions and ages of the dated samples. Italic numbers on the left are sample numbers; standard numbers on the right are the ages.

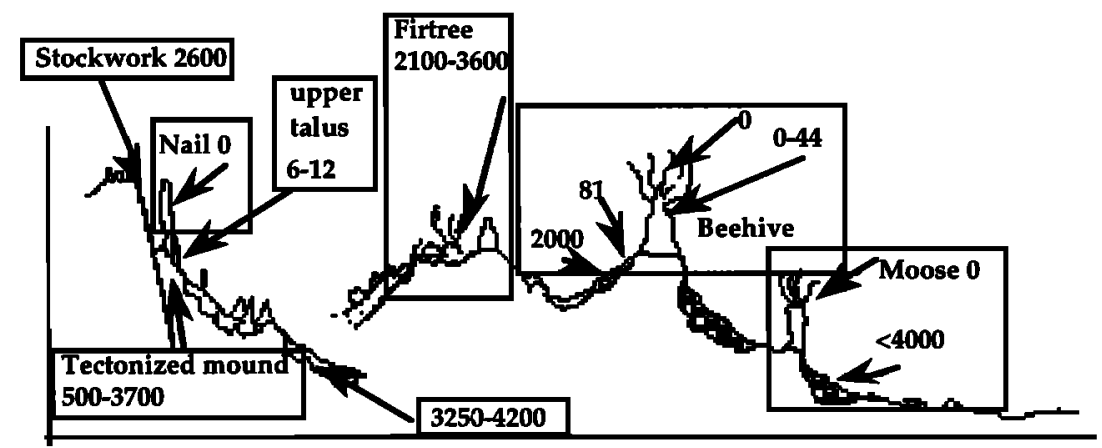

Fig. 9. Same as Figure 8 but where only the principal age groups for each site are noted.

The Moose Site. The Moose is an active chimney on the eastern flank of the ridge at a greater depth than the Beehive site $(3476 \mathrm{~m})$. Sample HS 03-01 ( $<4$ years) shows that this chimney is presently forming. No old samples have been recovered.

At a greater depth than the Moose site, near ODP site 649 on the talus mound, an Alvin 1986 sample, A 1683-3, was dated at $>200$ years and $<4000$ years, which can be interpreted as a maximum age due to a slight pollution with $232 \mathrm{Th}$.
The Firtree Site. This site, on the central ridge is described as a site with no active black smokers. Past activity is indicated by the presence of a mound as high as $22 \mathrm{~m}$, and, at its foot, by the diffuse emission of low-temperature waters $\left(3.8^{\circ} \mathrm{C}\right)$.

HS 05-01 (2100 \pm 350 years) is from the very top of the 22m-high mound in an area with small ( $<1 \mathrm{~m}$ high) sphaleritedominant chimneys. HS 05-02 is a massive pyrite boulder from the base of the Firtree in an area where the warm water was 
discharging; it has an age of $3600 \pm 600$ years. The 1986 Alvin dive collected, in the same area, one sample (1683-5) at the base of the Firtree ridge which gave an age of $<6000$ years. In an attempt to find the oldest possible samples during the 1990 dives, a sample (A 2193-4-1) was collected from the base of the site, in the same zone of shimmering waters as HS 0502 ; this sample gave an age of $2800 \pm 300$ years.

The Cliff site. The Cliff site, situated on the east facing flank of the graben has been created by a major tectonic event marked by a fault. A reactivation of this main fault, brought to the surface, in the northern part of the Cliff, a vein of stockwork [Mevel et al., 1989]. The major part of the wall is covered by blocks of sulfide and basalt on which some chimneys have been erected, the principal one being the Nail, on the southern end of the Cliff.

Three different zones of mineralization are clearly seen:

The active zone is situated around a presently active chimney: the Nail. Water issuing from the Nail has temperatures of 325 to $345^{\circ} \mathrm{C}$. Samples collected from the active chimney (HS 06-07, HS 08-01, HS 08-02) give ages around zero. Recent massive sulfides are found at the foot of the Nail, resting on a tectonized mound of sulfide. These samples (HS 10-06, A 1683-8, and HS 11-05) have ages from $<6$ to 26 years.

The second zone, presently inactive, is represented by the sulfide tectonized mound which is formed mainly of talus at the foot of the fault scarp. From the base of this area, sample A 2193-5 gives an age of 3700 years, and a sample recovered at the top of this formation, HS $11-03$, is 3200 years old. Farther down the Cliff, samples HS 06-06 and 06-05 give ages of 3250 and 4200 years. $\mathrm{Cu}$-rich stockwork veins visible between the pillow lava are presumably related to this episode.

By contrast, sample A 2193-6 from the base of this area, gives an age of 875 years, and similarly sample A 1683-6 [Lalou et al., 1990] from the same area gave an age of 500 years. Both these samples give ages that are at the limit of our analytical technique and must remain suspect.

The third zone is the stockwork. Two samples from this formation HS 11-06 and HS 11-08 give ages of 2500 \pm 900 and $2850 \pm 500$ years, which indicate that the reactivation of the fault has occured since 2500 years B.P. Figure 9 is a simplified chronological cross section of the Snakepit hydrothermal field.

After the hydrothermal field sampling during the Hydrosnake expedition was completed, further dives were made to study the western wall of the axial valley between the Kane fracture zone (FZ) and the Snakepit site. During one of the dives on the western flank near the intersection with Kane FZ, a sample, HS 16-05, presumably of hydrothermal origin was recovered. It is made of pyrolusite, birnessite and goethite, it is uranium rich (13.7 ppm) and 230 Th is at equilibrium with $234 \mathrm{U}$, so that only a minimum age of about 350,000 years may be estimated.

\section{Discussion AND CONCLUSION}

In studies based on deep-sea samples, it is always a problem to know if the sampling will give an unbiased treatment of the phenomenon under investigation. In the case of hydrothermal activity, it is clear that the present-day activity is oversampled relative to fossil deposits for at least two reasons. The first is that the active edifices are more striking and visible than old sulfide debris. The second is that old deposits have been partially altered and destroyed or are covered by sediment or even by lava flows. Nevertheless, in the case of the TAG and Snakepit fields, special attention was paid to the recovery of fossil deposits.

This chronology allows us to draw some conclusions about the temporal evolution of the MAR hydrothermal events and to compare this evolution to that one of the faster spreading EPR ridge.

In all fields, the lifetime of the present hydrothermal event is short, less than 100 years in the TAG area (possibly only 50 years), perhaps less than 200 years in the Snakepit area (dependent on the age of sample HS 05-03), but certainly 80 years. As it has already been shown on the East Pacific Rise $\left(13^{\circ}\right.$ and $\left.21^{\circ} \mathrm{N}\right)$, and taking into account the standard deviation of the $210 \mathrm{~Pb} / \mathrm{Pb}$ method which is approximately \pm 6 or 7 years, the chimneys grow very rapidly, having the same age at top and bottom; they may be still active even after 50 years (e.g., TAG Kremlin chimneys, or Snakepit chimney HS 03-02) or be young and already dead (e.g. HS 10-03) this arising from being plugged very rapidly after their construction, the plug and the walls having the same age.

In each field, the activity is episodic: In the upper part of Figure 10 (the TAG field), are shown the time scales of different periods of activity (low temperature and high temperature), as well as the ages of nonactivity shown by the aragonite precipitation. On the lower part of Figure 10, on the same time scale, are shown the results for the Snakepit field. At the TAG area, there have been numerous episodes of activity covering 140,000 years as registered near the axis and on the eastern wall of the valley. Moreover, on the presently active mound, which is only $200 \mathrm{~m}$ in diameter, we find superimposed at least four episodes of activity from 18,000 to 4000 years, indicating that the same paths for hydrothermal fluids can be reactivated, even after a complete stop as indicated by the aragonite precipitation. Intermittent activity was also probably the case for the fossil mound higher up the slope where samples of $100,000,50,000$ and 10,000 years are found in close proximity. Higher up the wall, the $\mathrm{MnO}_{2}$ episodes cover the whole time span from 125,000 to 4000 years (Figure 6). Due to the topography of the central valley of the MidAtlantic Ridge, in which the active zone is surrounded by high and relatively steep walls, and to the slow spreading rate, the hydrothermal deposits stay for a longer time in the axial graben.

At Snakepit, no fossil samples older than 4000 years have been found, nor any aragonite deposits. At least two events exist, one around 4000-2000 years ago and one presently active, again indicating intermittent activity at the same site.

In Figure 10, it may be seen that the Snakepit field is much younger than TAG, and that its activity began during the last period of quiescence of the TAG field about 4000 years ago. So, at the scale of our study it may be concluded that these different segments of the MAR are not linked in time with respect to hydrothermal activity; this is not surprising considering the large offset of the Kane fracture zone.

By comparison, on the EPR active and fossil sulfides are not found at the same site, moreover old deposits are not found in the central graben. At $13^{\circ} \mathrm{N}$ fossil deposits were found on a mound $4 \mathrm{~km}$ from the axial graben (Lalou et al., 1985), and, at $21^{\circ} \mathrm{N}$, they were found $800 \mathrm{~m}$ from the spreading axis (Lalou and Brichet, 1982). Samples older than 100 years have not been found in existing fields in the axial graben.

The main implications of this study are that hydrothermal 


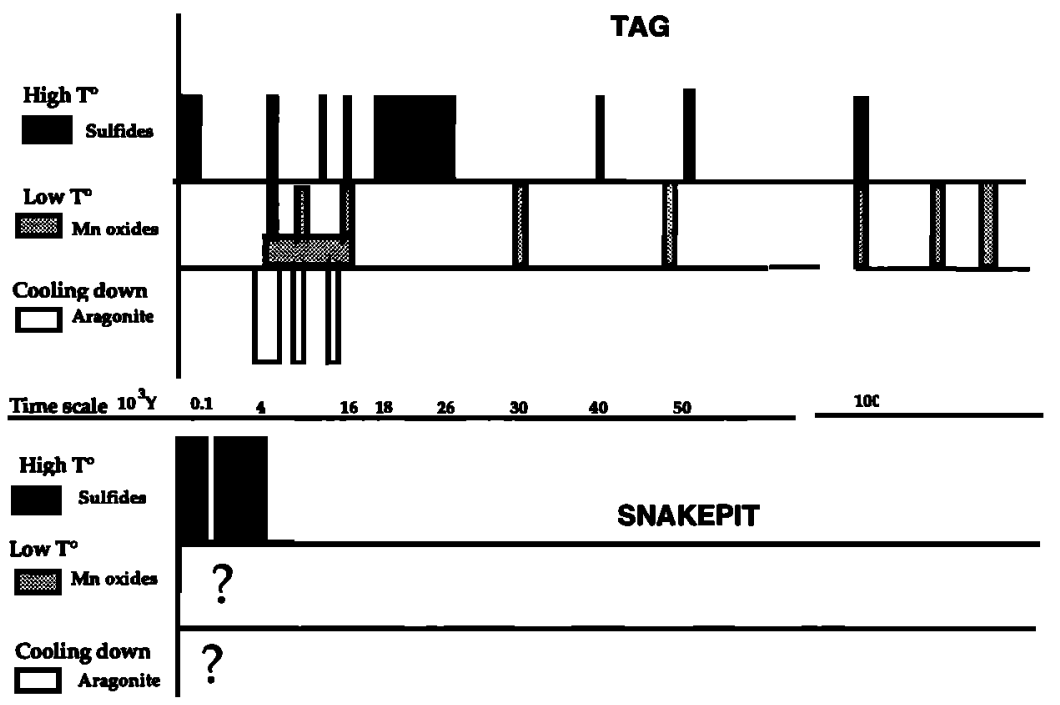

Fig. 10. Hydrothermal events on a time scale from 0 to about 130,000 years for the TAG field in the upper part of the diagram and for the Snakepit field in the lower part of the diagram. Snakepit activity during a period of quiescence at TAG is clearly shown.

manifestations, including the size of the deposit, vary according to the tectonic environment. Further, the geochronological study of hydrothermal precipitates can give important clues to the timing of magmatic-tectonichydrothermal activities during seafloor spreading on a time scale much finer than given by magnetic reversals.

Acknowledgments. We thank the captains and crews of Atlantis II and DSRV Alvin and of Nadir and DSRV Nautile, and C.Mevel, Chief Scientist of the Hydrosnake program for their help. We thank anonymous reviewers for their constructive comments. Financial support was received from CNRS-CEA and PNEHO for C.L., J.L.R., E.B., and M.A.; from NSF through grant OCE-9013150 for G.T.; from IFREMER for Y.F; and from NOAA VENTS program for P.R. This is CFR contribution 1322 and WHOI contribution 7716.

\section{REFERENCES}

Karson, J. A., et al., Along axis variations in seafloor spreading in the MARK area, Nature, 328, 681-685, 1987.

Lalou, C., and E. Brichet, Age and implication of East Pacific Rise sulphide deposits at $21^{\circ} \mathrm{N}$, Nature, 300, 169-171, 1982.

Lalou, C.,and E.Brichet, On the isotopic chronology of submarine hydrothermal deposits,Chem.Geol. 65, 197-207, 1987.

Lalou, C., E. Brichet, and R. Hékinian, Age dating of sulfide deposits from axial and off axial structures on the East Pacific Rise near $12^{\circ} 50^{\prime} \mathrm{N}$, Earth Planet.Sci. Lett., 75,59-71, 1985.

Lalou, C., G. Thompson, P. A. Rona, E. Brichet, and C., Jehanno, Chronology of selected hydrothermal Mn oxide deposits from the Trans Atlantic Geotraverse (TAG) area, Mid- Atlantic Ridge, $26^{\circ} \mathrm{N}$. Geochim. Cosmochim. Acta, 50, 1137-1143, 1986.

Lalou, C., G. Thompson, M. Amold, E. Brichet, E. Druffle, and P. A. Rona, Geochronology of TAG and Snakepit hydrothermal fields, Mid-Atlantic Ridge: Witness to a long and complex hydrothermal history, Earth Planet. Sci. Lett.,97, 113-128, 1990.

Lalou, C., J.L. Reyss, and E.Brichet, U-series disequilibrium as a tool to establish the chronology of deep sea hydrothermal events, Geol.
Soc. Am. Abstr. Programs, 23 , A115, 1991.

MAR Hydrothermal Research Team, Mid-Atlantic Ridge hydrothermal processes, Eos Trans. AGU, 71, 726-727,1990.

Mevel, C., et al., La ride du Snakepit (dorsale médio atlantique $23^{\circ} 22^{\prime} \mathrm{N}$ ): Résultats préliminaires de la campagne Hydrosnake, $C$ R. Acad. Sci., 308, 545- 552, 1989

RISE Project Group, East Pacific Rise: Hot springs and geophysical experiments, Science, 207, 1421-1433, 1980.

Rona, P .A., Marine geology. in McGraw-Hill Year Book of Science and Technology, pp.. 252-256, McGraw-Hill, New York, 1973.

Rona, P.A., G. Thompson, M. J.Mottl, J. A. Karson, W. J. Jenkins, D. Graham, M. Mallette, K. Von Damm, and J. M. Edmond, Hydrothermal activity at the Trans-Atlantic geotraverse hydrothermal field, Mid-Atlantic Ridge crest at $26^{\circ} \mathrm{N}, J$. Geophys. Res., 89, 11,365-11,377, 1984.

Rona, P. A., G., Klinkhammer, J. A., Nelsen, J. H. Trefry, and H. Elderfield, Black smokers, massive sulfides and vent biota at the Mid-Atlantic Ridge, Nature, 321, 33-37, 1986.

Scientific Party Leg 106, Mid-Atlantic bare-rock drilling and hydrothermal vents. Nature, 32I, 14-15, 1986 a.

Scientific Party Leg 106, Drilling the Snakepit hydrothermal sulfide deposit on the Mid-Atlantic Ridge, Lat. $23^{\circ} 22^{\prime} \mathrm{N}$, Geology, 14. 1004-1007, 1986b.

Thompson, G., S. E. Humphris, B. Schroeder, M.Sulanowska, and P. A.Rona, Active vents and massive sulfides at $26^{\circ} \mathrm{N}$ (TAG) and $23^{\circ} \mathrm{N}$ (Snakepit) on the Mid-Atlantic Ridge, Can. Mineral., 26, 697-711, 1988.

M. Amold, E. Brichet, C. Lalou, and J. L. Reyss, Centre de: Faibles Radioactivités, CNRS-CEA, 91198 Gif sur Yvette Cedex, France. Y. Fouquet, Ifremer-Brest, BP 70, 29280 Plouzane Cedex, France. P. A. Rona, NOAA, 4301 Rickenbacker Causeway, Miami, FL 33149

G. Thompson, Woods Hole Oceanographic Jnstitution, Department of Chemistry, Woods Hole, MA 02543.

(Received June 3, 1991 revised August 3, 1992; accepted August 11, 1992.) 